sity must also be investigated if any satisfactory result is to be obtained. To get exact results in experimental psychology in general is then, I am persuaded, an enormously difficult task. The complexity of adult human consciousness is so great that it seems well nigh impossible to isolate the factors we are studying, and to secure identical reactions in a sufficiently large number of cases to prove a psychic law. Physical conditions are far more under our control than psychical, and are far easier to observe, and hence physical science has arrived at a consensus which is notably lacking in psychical. Essential preliminaries must first be settled before experimental psychology can really be fruitful, and the relation of attention to intensity of sensation requires far closer definition of subject and method than has yet been given it, if results of large scientific value are to be obtained.

Hiram M. Stanley.

LAKE Forest UnIVERSITY.

\title{
PLEASURE-PAIN AND EMOTION.
}

Serious and courteous criticism from the pen of a thmker, skilled in the subject of discussion, is certainly in all cases to be welcomed by an author, and I feel much gratification in reading Dr. Santayana's remarks upon my lately-published book ${ }^{1}$ in the July number of this Review.

There are one or two points raised in the review which I think it worth while to discuss.

In the first place, in the interest of psychological advance I must deprecate the implication of the opening paragraphs; viz.: that the writer of what aims to be a scientific discussion of pyschologic doctrine is no great sinner if he consider the clams of literary æsthetics in his exposition, where there is the slightest chance that the clearness and definiteness of his meaning may thereby suffer.

I regret much more than my critic can do that the book is so unattractive in its literary quality, but on the whole I do not feel confident that I could have made it more pleasing had I not deemed it of the utmost importance to aim at accuracy and to waive verbal preferences in favor of precision.

I am free to confess that the reading over and over again of my proofs has produced within me a deep-seated digust with many phrasess in the book, notably with the compound word pleasure-pain; but what authorized substitute could $I$ have used in this case save the word

1 Pain, Pleasure and Esthetics. 
'feeling'?-a word which is truly much more euphonious than the one employed, but entirely devoid of accuracy. I do not wish to excuse the evil complained of by my critic, a cleverer writer might have overcome it; but I think that it would have been all wrong to have chosen in any case literary worth as against definiteness, in such a work.

I rase this point principally because I feel that psychologists today are too often careless in this regard. They are too apt to discard in disgust an awkward but accurate term or phrase and to use in its place something of better æsthetic quality but decidedly inferior in definiteness. Or they go even further and add emphasis to unimportant particulars by the attractive nature of some form of speech or of some chance illustration. The extraordinary misconception of Prof. James' emotional theory by other psychologists, to which he draws attention in the September number of this Review, may in my opinion be partly accounted for in this way. I have in mind a case in which I myself entirely lost the drift of an interesting argument presented in a paper read before the last meeting of the Psychological Association, because my mind refused to be dragged away from the æsthetic contemplation of a happily-used and beautiful quotation to the hard thinking required in following the course of the argument.

In the field which I touch the preference of euphonious but inaccurate terms and phrases, where 'barbarous' but accurate ones could be found, has been especially unfortunate in result.

I am very sure, for instance, that much of the voluminous literature of the subject of which I have treated would have remained unpublished had the authors avoided the use of 'Gefiul' in German and 'Feeling' in English. Had they used 'pleasure-pain' (or some better equivalent) when and only when they meant it and nothing else, many of their most effective periods would have become evidently illogical or irrelevant. My critic shall furnish me with an example of the danger. It is much pleasanter to speak of the æsthetic as determined by pleasures of memory, than by pleasures of revizal; and to avoid repetition I did give way once, I believe, and use that term in one of the statedly popular summaries. But the pleasures of memory are not all that I refer to. A memory is a special kind of revival. Revival therefore is a much broader term than memory. What I refer to are revival pleasures, and the use of the word memory in this connection at once limits the thought of the reader to definite objects : With my critic, the notion that the two 
terms are interchangeable has led him at times to misconceive to some extent the thesis presented for examination.

What has worried me indeed has been not so much the failures of style, to which Dr. Santayana calls attention, as the consciousness that I may possibly have been guilty of the very faults of inaccuracy that I deplore in others.

But to turn to the criticism itself, I have no desire to combat objections raised except where they seem to involve misapprehension, and I am glad to say that I think all of Dr. Santayana's oppositions, as expressed, will disappear upon a clearer apprehension of my meaning.

I hold that there is no "clear distinction between the sense of pleasure and the sense of beauty" in impression: and these last two words, that I add, are of the very essence of my thesis. The distinction which is noticed is one made in judgment upon revivals. With these two words added to Dr. Santayana's expression I have no hesitation in leaving the cases he brings forward to introspective tests. I am sure that for myself when "I have no definite object before the mind, but am lost in a torpid reverie" which is pleasant, the state of impression is indistinguishable from many of the impressions that are called distinctly æsthetic ; $\iota . g .$, the impressions coming to me as I listen to some parts of Wagner's 'Tristan and Isolde'; and I have no hesitancy in holding that if an object afterwards to be judged beautiful were to appear in connection with this reverie, the pleasures of æsthetic impression connected with this object would completely fuse with those of the 'torpid reverie. ' The point of difference lies just in the distinction between the xsthetic judgment and the æsthetic impression, the former of which always relates to objects or objective states. In this particular case the revival of the state of 'torpid reverie' is necessarily associated with the torpid object, and for most people such torpid objects or their mental states are, in revival, so very insipid that they cannot be noticed to be pleasurable and are therefore judged to be unæsthetic. Dr. Santayana says "but this pleasure" (of torpid reverie) "would not be æsthetic, because I could not perceive any beauty, seeing that no object is present to me in which that beauty may reside." By the words 'would not be æsthetic' he certainly means "would not be called or thought of in retrospect as æsthetic"; he is speaking of what I consider to be a judgment as to the nature of revivals. His words, however, would lead one to think that he considers this phrase to relate to the direct nature of the impression. 
The other case mentioned by my critıc is also, I think, distinctly in my favor. It is perfectly true that "few pleasures are so vivid in revival as those of satisfied vanity, affection, revenge and other personal passions," and so far as I have indulged myself in these intoxicants I feel sure that I have been xsthetically impressed at the time. I am unable to draw any distinction between these pleasurable impressions, so long as they remain mere impressions and those other impressions produced by what is acknowledged to be beautiful. The distinction comes in the revivals upon which we act in judgment, when the despicableness of the self-complacency brings a balance of pain to a man who is properly constituted. My critic's examples, indeed, are not here very forcible, for, in the revivals of the 'personal passions' mentioned, I am usually distinctly judging of myself as worthy in some respect and therefore as an esthetic object.

There is another direction in which I wish to malse my position clearer. I am one of those who think that too much emphasis is given to-day in some quarters to the physiological basis of psychology. I am heartily in sympathy with any investigations that can throw light upon psychology, and I thınk the patience and persistency of our experimenters in psychophysics is most noble, and, except so far as it is misapplied, it certainly should be most heartily encouraged and applauded. On the other hand, I feel with many of the advanced neurologists that we can only claim to be beginning to understand the nature of those neural changes which form the basis of psychic life. I do not feel sure that our present notions of the relation between mind and body may not seem very crude in a few centuries from now, just as those held by the Greek philosophers do to us to-day.

Just here it will be convenient and appropriate to call attention to a point which relates to this subject-matter, and which supports the view just expressed. Two years ago I). H. Nichols published in the Philosophical Review a defence of a theory that pains are a species of sensation. I argued in a reply, which appears again in my book, that this view is opposed to psychological evidence, and that the facts, mainly physiological and histological, upon which the theory depends for its support are, with possibly one exception, entirely compatible with other deductions than those made by those upholding the sensational theory. This one exception was the claim made that Goldscheider had discovered definite nerve-terminals for pain in the skin. I objected that in this field the statement of one observer of a limited number of subjects should be received with caution, and I further noted that Goldscheider had implicitly denied the 
position involved in his first statement as it was interpreted, and upon which interpretation Dr. Nichols founded his argument. Dr. L. Witmer has lately reiterated Dr. Nichols' theory in the Journal of Nervous and Mental Diseases for April, 1894, and has sharply called me to task for being unwilling to accept as final Goldscheider's supposed dictum. Dr. Collins, in his review of my book in the same journal, has made the same criticism of my position in this respect. But now there comes to hand a new book by Goldscheider.- 'Ueber den Sckmerz,' Berlin, 1894, - which serves I think to teach a lesson to all psychologists, and especially to those who may have taken interest in this discussion; for in this book Goldscheider distinctly denies the view which has been thus attributed to him, and seems to think he cannot properly have been held to be a defender of a position so evidently untenable; although I think his words in his early publications certainly spoke clearly as they have been understood. Goldscheider now holds (p. 7) that Schmerz is "eine besondere Qualität der Empfindung, nicht eine allen verschiedenen Qualitäten gemenschaftliche Modifikation der Empfindung." Further (p. 13), "dass die Schmerzempfindung den Drucksinn and Gemein-gefühlsnerven eigen ist, allen übrigen Sinnesnerven aber fehlt." I do not appreciate upon what sufficient grounds he bases his belief in the existence of these Gemeingefühlsnerven (see also p. 33) and of the Gemeingefühlserregungen spoken of elsewhere (see p. 8). He tells us further (p. 18), "Hiernach läge es in der That nahe, jeden Schmerz als ein Summations-Phänomen anzusehen, allein dies gilt nicht ausnahmslos": and he postulates a 'Summations-Organ' (see p. 34) located in the spinal cord (see p. I9) to account for the effects of pain. It does not seem to me that we should receive without caution the statements of an investigator who makes such free use of unverified hypotheses.

Goldscheider in this new treatise, if he does nothing else, shows conclusively that our knowledge of the nature of the neural changes which are the coincidents of pain consciousness is of the most indefinite character, open to dispute in every direction, and that no physiological or histological theory relating thereto can to-day be held to be proved. Moreover, so far as I can see, there is little reason to lead us to hope that we shall be able to reach any settled position in this respect in the near future.

This occurrence strengthens within me the conviction with which I wish more of our psychologists clearly showed their sympathy, that introspective psychology must move on in her development without waiting for the positive teaching of psycho-physics; she 
must of course endeavor to check the results of introspection by what becomes known through psychological investigation; but it would surely be a great loss to philosophy and to science in general if psychology hesitated in her course while awaiting clear light from this source.

This being my view, it was with regret that I found it impossible to discuss adequately in my book that which has been done in the past in reference to the physiological basis of pleasure and pain, and to suggest the direction in which the facts before us vaguely point, without giving relatively much more space to the subject than its importance warrants.

I am disappointed, moreover, to find notices of the physiological theory so prominent in the reviews of the book, and especially to find Dr. Santayana in this review taking for granted that the basis of my æsthetic principles is to be found only in this necessarily vague physiological theory. In fact if the reader will take the trouble to examine the matter he will find that the basis of these æsthetic distinctions and principles is really determined by introspective evidence and not derived from physiological hypotheses; and that the physiological correspondence, as it would appear under my theory, is generally stated in the chapters dealing with these principles, in small print in brackets. Thus it appears indeed that the psychological æsthetic principles give us a very strong corroboration of the physiological theory, but I do not feel that it is evident that these rsthetic principles necessarily fall if the physical theory crumble into dust, as is implied in this review, and as has been asserted by Dr. Jos. Collins in the review in the Journal of Nervous and Mental Diseases above referred to.

It is because I feel the secondary importance of this physiological view that I am also greatly disappointed to find my critic holding that my main psychological thesis turns upon a mere matter of words. I had hoped to show that this psychological thesis has strength; and that, so far as our knowledge of the physiological aspect of the subject goes, the psychological view is not incompatible with that knowledge ; for I seem to see that if the psychological view be true, and if it be carried out to its consequences, it may lead to results in other directions than those especially studied that may provie to be interesting at least; and I had hoped that the results as brought forward in relation to the emotions, the art impulse, and the principles of æsthetics, might appear to be not wholly valueless, altogether apart from any physiological theory whatever. As this psychological theory is in my view thus important, I trust that it will not appear 
out of place if I try to convince my critic that it is a great deal more than a mere verbal contention that I make.

In the first place I may again call attention to the dangers attendant upon the asthetic treatment of what should be strictly accurate science. Dr. Santayana's statement of my proposed definition of pleasure and pain is probably pleasanter to his ear than my own. He states that I hold them to be "qualities either of which may and one of which must belong to every perception of the mind." But this is not the doctrine I have expressed, unless my phrase 'each element of consciousness' is made equivalent to his 'every perception of the mind.' I do not think the two expressions are at all synonymous, and I believe that one must avoid the statement as made by him if one is to grasp correctly the thesis and its implications.

But passing over this inaccuracy, let us turn to his argument itself. It is perfectly true that we may equally well say "that color is a quality of extension, or that they are two simultaneous perceptions, or that they are both qualities of a present substance." But is it no gain to take note of the fact that at times when there is no color perception at all there still may be a consciousness of extension; that other sensations and mental modes than color sensations have this consciousness of extension connected with them ? Is no importance to be attached to the thesis that extensity may be a quality of very wide application? Can it justly be held that the contention of the present day in relation to space, which turns upon this thesis, and in which the greatest psychological thinkers of our time are involved,- - that this contention 'turns upon a matter of words,' 'becomes real and not verbal only in the field of physiology' ?

Or to take another instance more to my liking. The intensity of a color may be treated as Dr. Santayana treats its extensity. It might be said that the facts may be "described equally well by saying that color is a quality of" intensity, "or that they are two simultaneous perceptions, or that they are both qualities of a present substance." But is it no gain to psychology that more or less of intensity is acknowledged to be a quality attached to all elements of consciousness? Would it be of no value to make contention for this doctrine were psychology in so crude a state that some masters held 'intensity' to be a species of sensation ; others that it is a kind of emotion; others that it is the fundamental basis of all psychic life; others of great weight that a special kind of mind, apart from our cognitive mind, must be postulated to enable us to grasp intensity -i. e., that intensity is a mental mode sui generis? Could such con- 
tention, if it were necessary, be held to turn upon a mere matter of words, and to become a real question 'and not verbal only in the field of physiology'? It is such a contention as this that I make for pleasure-pain.

HenRy RUtgers Marshall.

NEW YORK.

\section{A COMMENT.}

In Wundt's article, Zur Lehre zon den Gemüthsbewegungen (Phil. Stud., vi, p. $3^{64}$ ), occurs the following passage:

Die Apperception selbst ist nichts, was den Effecten, die sie am Vorstellungsinhalte erzeugt, und den Begleiterscheinungen, die sie im Gebiet des Gefühls hat, als etwas besonderes, realiter zu trennendes gegenüberstände. Vielmehr besteht sie selbst nur aus diesen Begleiterscheinungen und Wirkungen.

Professor James exclaims, dpropos of the last sentence: "A thing that 'consists' of its concomitants!" (This Review, I, p. 516.) The exclamation is hardly fair criticism. We read, p. 390 of the same article:

$\mathrm{Zu}$ jenen Begleiterscheinungen reche ich in erster Linie gewisse $z u$ Vorstellungen vereinigte Empfindungen, in zweiter Linie die Willensacte theils vorbereitenden theils mit ihnen unmittelbar verbundenen Gefühle. Die letzteren lassen sich jedoch nur auf Grund der einmal vollzogenen abstracten Unterscheidung $z$ wischen Fühlen und Wollen Begletterscheinungen des Willens nennen. In Zusammenhang mit der Entwickelung des Willens betrachtet, verwandeln sie sich selbst in Elemente der Willensthätigkeit, die sich aber deshalb, weil aus ihnen nicht immer ein actuelles Wollen hervorgeht, nun auch in solchen Fällen, wo dieses eintritt, demselben als begrifflich trennbare Bestandtheile gegenüberstellen lassen.

It is, of course, really not much fairer to quote two passages without context than it is to quote one. But the second of the above citations may serve to show that Professor James' scorn is not so undoubtedly merited as might at first sight appear.

E. B. Titchener. 